\title{
Towards a positive pedagogy: designing pedagogical practices that facilitate positivity within the classroom
}

\author{
Dr Mia O’Brien \\ Dr Levon Blue \\ Griffith University, School of Education and Professional Studies, Mt \\ Gravatt, Australia
}

Published version available from:

http://www.tandfonline.com/eprint/uQ89ifN4gwupM5J8uTEH/full

\begin{abstract}
Students flourish by having positive learning experiences at school. Here we describe an action research study undertaken in an Australian primary school that was intended to promote the development of students' positive learning identities and resources. We partnered with classroom teachers to devise pedagogical practices that explicitly targeted the development of students' positive cognitions, positive emotions and positive experiences. Two main lines of inquiry guided the action research: i) what might 'positivity' look like in relation to learning, for students within primary school classrooms? and ii) what kinds of pedagogical practices promote positivity within the classroom? Data were collected over an 18-month period and drew from two cycles of action research which generated teacher reflections and interviews, observations of classroom teaching and learning episodes, rich descriptive field notes, anecdotal feedback from parents, as well as student reflections and student focus group interviews.
\end{abstract}

Practice theory was used to analyse the data. Our findings indicate that there are explicit learning behaviours and dispositions that represent positivity in a learning context; and we identify pedagogical practices effective for fostering these behaviours and dispositions. These practices, referred to here as positive pedagogies, include teacher talk, social and emotional resources for students, the supplementation of lessons with resource building materials, and the development of individualised learning goals that target the development of positive cognitions, emotions and experiences. We provide a detailed commentary of the action research cycles (and related professional learning) that classroom teachers undertook in the process of contributing to the 'positive pedagogies' presented. 


\section{Introduction - focus and rationale for the project}

At the heart of this study is the dual purpose of education - to enable people to live well in a world worth living in (Kemmis et al. 2014). Dewey $(1897,1916)$ articulates a distinction between education (as an opportunity for children to realise their full potential and ability, to learn to 'live') and schooling (the acquisition of a predetermined set of skills and knowledge). Education, as opposed to schooling, aims to develop children's self-awareness, agency and experience of full human capacities (Dewey 1897). This study began in response to a shared felt concern that the impositions of mandated national testing and prescribed curriculum constrained the teachers' capacity to deliver a wholly positive and engaging experience of learning for their students. In essence, it was a reaction to counter the current emphasis on standardised testing in an ‘era of accountability’ (Comber and Nixon 2001; Hardy 2014), to reflect on practice (Lutternberg, Meijer and Oolbekkink-Marchand 2017) and a moral obligation to act (Ponte and Rönnerman 2009).

Kemmis et al. (2014) suggest that within this educative stance is an explicit concern for teaching and learning practices that initiate our children into certain ways of being in the world. These include the

(1) forms of understanding that foster individual and collective selfexpression, (2) modes of action that foster individual and collective selfdevelopment, and (3) ways of relating to one another and the world that foster individual and collective self-determination, and that are, in these senses, oriented towards both the good for each person and the good for humankind. (Kemmis et al. 2014, 88).

The teachers in this study (hereafter the teachers) were each committed to these aspirations, but all felt that the constraints of the professional environment 
presented impediments to achieving these aims. For them, the immediate challenge was to find ways to expand and extend their personal professional knowledge and practice, and to find ways to facilitate their educative intentions amid the limitations of the increasingly prescribed environment. The first named author (hereafter researcher) was brought in as critical friend/co-researcher to facilitate this process, and together a central guiding research question was devised: What kinds of pedagogical practices can facilitate a positive experience of learning for students in the classroom?

\section{Problem analysis and conceptual framework - building positive learning identities}

Teachers play a central role in the development of children's cognitive, academic and social-emotional growth (Hughes, Bullock, and Coplan 2014; Mertens 2014). Next to the caregiving and pastoral care role that teachers offer, the pedagogical relationship can have enormous influence over the kinds of experiences that shape children's selfbeliefs, perceptions and cognitive, social and psychological resources. A student's school experience qualitatively shapes important developmental milestones such as motivation, identity development and overall academic success (Gilman, Huebner, and Furlong 2014) and wellbeing (Shernoff, 2013). Pietarinen, Soini, and Pyhalto (2014) found that students’ cognitive engagement was highly mediated by the quality of particular interrelationships: those between the student and other students, between the student and teachers, and more broadly, the nature of the pedagogical practices experienced on a daily basis. A student's overall sense of well-being related to school was found to be a key determinant in their emotional and cognitive engagement. Indeed, specific forms of teacher support have been identified as enhancing students' sense of academic confidence, their ability to regulate their own learning and a sense 
of mastery learning, and to improvements in both social and emotional engagement (Skinner, Kindermann, and Furrer 2009; Wu, Hughes, and Kwok 2010). Similarly, teacher-student relationships that are characterised by closeness and low levels of conflict have been found to result in lower levels of behavioural problems (Silver et al. 2005). There is a strong link between emotional engagement within teacherstudent relationships and a student's future academic achievement and social and behavioural outcomes (Pianta and Stuhlman 2004; Wang and Holcombe 2010).

Pedagogical practices play a significant role in facilitating quality student engagement. Especially in developing the kinds of enabling social environments and systems that have the strongest influence on students' cognitive and emotional engagement (Pietarinen et al. 2014). However, teachers do not necessarily feel well prepared in this area of professional practice (Australian Education Union 2009; Shernoff 2013; Willms 2003). The teachers shared a widely expressed concern for their students’ apparent lack of preparedness to learn, their disconnection from schooling, and an observable lack of cognitive, physical and psychological resources. For these reasons the teachers were primarily concerned with developing greater understandings about what these cognitive, physical and psychological resources might look like and how they might be fostered within the day-to-day realities of the classroom.

\section{What is positivity?}

Positivity is the study of human flourishing and the actions and activities of those who flourish (Dweck 2006; Fredrickson 2006; Lyubomirsky, Schkade, and Sheldon 2005; Park and Peterson 2006). A distinctive area of research within social psychology, positive psychology research has much to offer school-based practice and research 
(Huebner and Hills 2011), especially through the field's capacity to radically enrich and expand our professional practice paradigms.

There is strong evidence that positive emotions, character traits, cognitions and resources play a vital role in people’s capacity to engage positively and productively in life and work, and in maintaining an overall sense of well-being (Fredrickson 2006; Gillman et al. 2014; Huebner and Hills 2011). A positive disposition is associated with broadened capabilities, personal resources, and an increase in resiliency and coping skills when faced with challenges (Fredrickson 2006), all of which are vital to learning in school. These traits, characteristics and interactive preferences associated with positivity are not inherent in human functioning. Indeed, children and young people identified as 'at risk' are commonly found to be without these resources (Benson 2007). It is possible to build positive personal strengths, assets and potentialities effectively (Fredrickson 2009; Peterson and Seligman 2004; Lyubomirsky et al. 2005) and the schooling sector has been quick to devise interventions for this purpose (Furlong, Gilman, and Huebner 2014; Shernoff 2013).

In this way, experiencing positivity relies on the conscious deployment of personal, cognitive, psychological and social resources, which are qualitatively shaped within the family and social situations in which we live and grow (Fredrickson 2006). While there has been some rapid development of research-based strategies for enhancing these resources (Fredrickson 2009), Gilman et al. (2014) note that there remains a genuine need for more research on the development of school-based interventions in positivity. Indeed, identifying classroom practices that build children’s cognitive, psychological and social resources for learning remains a priority, as these resources play an important role in bolstering children's capacity to 
counter the learning, social and intrapersonal struggles that characterise schooling (Gillman et al. 2014; Huebner and Hills 2011; Shernoff 2013).

\section{Theoretical and methodological approach}

This study was anchored within a praxis perspective - a stance that acknowledges the moral and ethical nature of teaching and learning (Kemmis 2012, 2010; Grootenboer 2013; Kemmis et al. 2014). Theoretically, this study was about practices, and more specifically about changing practices. This positions research as 'a dialogue between practice philosophy and theory and the empirical cases’ that we study (Wilkinson and Kemmis 2014, 6). It entails a study of practices in the mode of research within practice traditions, described as practical philosophy (Carr 2007).

In an educational praxis paradigm the theorisation of teaching and learning occurs as a process of 'researching practice from within practice traditions' (Kemmis 2010, 18). This project took place within a school and the researcher worked in partnership with classroom teachers (practitioners) to inquire into an identified felt concern. This methodology places practitioners in the centre of the analytic frame as they move through the process of transforming how they understand their practices, how they conduct their practices, and the how they interpret and respond to the conditions under which they practise. From an analytical perspective Kemmis et al's (2014) practice architectures provides a comprehensive theoretical lens through which to analyse classroom practice, and to investigate pedagogies that may potentially facilitate positive learning dispositions and resources for students. The original practice architectures diagram is reproduced here in Figure 1 and illustrates how qualities of intersubjective spaces (such as classrooms) are enabled and constrained by the practice architectures that hold these arrangements in place.

Figure 1 near here 
Methodologically, there was a critical lens applied to this inquiry that consistently required the researcher and practitioner team to consider the extent to which such practices were or could be more rational, productive and sustainable, just and inclusive. A critical participatory action research (CPAR) methodology informed the study design (Kemmis, McTaggart, and Nixon 2014). Together the researcher and classroom teachers investigated, considered and transformed classroom practices in ways that were intended to promote students' positivity of learning experience within the classroom.

\section{Research Setting and Participants}

The research site was an Australian suburban primary school located in South-East Queensland. The school has an above average rating on the index of community socio-educational advantage (ICSEA) when compared with other schools in Australia (on key factors such as parents' occupations, education levels, geographical location and the number of Indigenous students). The study took place over an 18-month period, unfolding over six school terms. The researcher/first-named author collaborated with the school leadership team and in particular with the school's pedagogical coach to facilitate real-time, on-the-ground activities that drove the study forward. This included providing regular support for teachers in their engagement with the action research process and focus, and in the collection and collation of data.

The action research participants were recruited as volunteers who selfnominated after a preliminary presentation on the study's focus to a whole-school staff meeting. Initially the study was established with three classroom teachers each with approximately 24 students across Grades 2 (6-7 years), 3 (8-9 years), and 4 (1011 years) in Terms 3 and 4 . The study expanded the following year to include 14 
teachers across each of the grades (Prep to Year 7) as well as one LOTE (languages other than English) teacher.

CPAR involves the researchers and participants in a collaborative process. It engages teachers in researching their own practice 'from within' (Kemmis et al. 2014). Engaging participants as researchers facilitates deep transformative experiences for practitioners and authentic insights into the practices (Makar and O’Brien, 2013). In turn, as the group strives to find intersubjective agreement on their understandings and practices and the conditions under which they practise, opportunities arise for the teachers (as insiders) to make decisions about, and act on, research into their own practices and practice traditions from within (Kemmis 2009).

In this way, the project was simultaneously:

(1) Technical - seeking to improve control over outcomes, to change practice to improve effectiveness, to focus on the practice of the practitioner, and to explore and identify pedagogical practices that might enhance (or impede) the development of children's positivity within classrooms;

(2) Practical - intending to educate or enlighten practitioners to act more wisely and prudently, to devise targeted pedagogical practices and resources that might promote the development of children's positivity within classrooms; and

(3) Critical -ascertaining how effective such practices and resources were in shaping the development of children's positivity within classroom learning, in ways that would make a felt difference to the children's experience of learning and self-as-learner.

\section{Research Focus, Design and Activities}


CPAR is initiated by the collaborative identification of a felt concern that focuses collective attention and intention (Kemmis, McTaggart, and Nixon 2014). This was captured and represented an action research cycle or project and the activity of this project proceeded through four broad stages: reconnaissance, planning, enacting the plan and observing how it works, and reflection (Kemmis et al, 2014).

\section{The Project of Research}

The project of this research was to identify practices that had the potential to promote students' positivity of self, of cognition, of emotion and of social and individual capabilities within everyday classroom learning environments. O’Brien defines positive learning identity as "those positively framed self-perceptions, personal values, psychological dispositions, and affective orientations, as well as the personal knowledge and academic capabilities, that the learner brings to bear in order to participate in, and make meaning from, a specific learning setting” $(2017,256)$. Our intention was to achieve beneficial changes in pedagogical practice; to facilitate critical, transformative pedagogy; and in particular to identify, build and refine pedagogical practices that promote students' sense of positivity in learning and their own positive learning identities.

\section{Data Collected Over the Phases of Action Research}

\section{Communicative spaces}

The action group agreed to meet regularly throughout the school term (approximately every fortnight), and this took the form of 'professional learning circles' - an established and well-known practice in the school. This provided a regular communicative space (Kemmis et al. 2014) where participant discussion was focused on the groups' shared felt concern - to promote positivity for students within the classroom. These discussions often included collaborative reflection on the local 
project (Ponte, 2006) and how positive practice would best work in each classroom. The aim of the communicative space was to build mutual understandings of how positivity and the related research could be applied to teaching and learning situations, or could inform pedagogical innovations. There was often a short reading or idea presented that teachers would consider for individual action research projects.

The focus of the meetings shifted to reflect the breadth of practices and experiences the teachers identified as relevant or worth discussing as they implemented their ideas. As is the aim within communicative spaces and CPAR, these ideas and practices were reviewed, critiqued, refined, and re-implemented.

Data collected from the communicative spaces included copies of meeting activities and resources circulated for the meetings (including readings or summaries of key ideas), notes of the meeting discussions as well as of individual attendees’ reports and updates on practices. Copies of specific classroom resources and plans devised by individual teachers were also circulated and collected.

Towards the end of each term the communicative spaces became opportunities for reflective evaluation, and these evaluations were considered as focus group interviews and were recorded and transcribed verbatim.

\section{Classroom practice in action}

CPAR researchers enact practices and practice traditions from within (enabling the incorporation of insider insights). To facilitate this practice in action, a series of classroom observations and videos were undertaken. These were lessons nominated by the teachers and included either specific lessons that aimed to introduce students to the positivity resources and practices, and/or standard classroom lessons that aimed to illustrate how that particular teacher was incorporating the resources or strategies into everyday classroom practices. 
Observations of these 'individual action research projects' implemented at the classroom level enabled a range of data to be considered. These data (both contextual and perceptual) were used reflexively to provide evidence to answer the research question regarding what pedagogical practices facilitate positive experiences of learning for all students (see Table 1).

Table 1: Types of data sought and methods used

\begin{tabular}{lll}
\hline $\begin{array}{l}\text { Type of } \\
\text { Information }\end{array}$ & Information sought by researcher & Method used \\
\hline Contextual & $\begin{array}{l}\text { Detailed classroom observations made in the field, as } \\
\text { the researcher observed multiple lessons to collect } \\
\text { evidence about aspects of the teachers' pedagogy } \\
\text { (such as the quality of his/her classroom talk) and } \\
\text { aspects of the students' experience (such as their } \\
\text { engagement in learning tasks or responsiveness to } \\
\text { teacher direction) }\end{array}$ & $\begin{array}{l}\text { Face to face } \\
\text { including-critical } \\
\text { friend and debriefing } \\
\text { sessions } \\
\text { Observations }\end{array}$ \\
& $\begin{array}{l}\text { Viewed teaching and learning episodes or lessons, } \\
\text { which offered an opportunity for event sampling } \\
\text { (noting the sayings/doings of the classroom as an }\end{array}$ & $\begin{array}{l}\text { Video taped } \\
\text { classroom lessons and } \\
\text { classroom } \\
\text { observations } \\
\text { (including debriefing) }\end{array}$ \\
& $\begin{array}{l}\text { action research project unfolded over time) } \\
\text { Focus group }\end{array}$ \\
& $\begin{array}{l}\text { Students reflected on and shared how they responded } \\
\text { to the teachers/researcher' questions about the work. }\end{array}$ & $\begin{array}{l}\text { Individual interviews } \\
\text { with students }\end{array}$ \\
& & $\begin{array}{l}\text { Student data also } \\
\text { included: drawings, } \\
\text { learning goals }\end{array}$ \\
& & Video taped lessons
\end{tabular}

Note. This table includes the type of information sought (contextual, and perceptual); the information sought; and, the methods used in this study.

The 'critical' in CPAR

CPAR involves monitoring individual and social practices and monitoring the understandings of practice. This deliberate practice sought to collect a range of evidence to inform critical intentions and to answer the question, 'to what extent was my practice achieving these intentions?' To answer this question a range of data were collected, including teacher reflections, student reflections and student comments.

\section{Teacher reflections}

The teachers agreed to verbally reflect on their experiences in both the professional learning communities and in individual interviews that occurred at opportunistic 
moments during the term (for example, during classroom observations the teachers would often make aside comments to the researcher or to offer a 5-10-minute stimulated-recall styled interview post lessons).

These became regular meetings facilitated by the researcher, and worked best when teachers met in pairs or groups of three to share findings from a cycle of implementation. At these meetings the teachers and researchers would share observations and anecdotes drawn from classroom episodes; and reflect on how effective these evolving practices and approaches were for enhancing student learning. These meetings provided a rich source of data, some of which provided contextual information, and some of which provided insights into the teachers' perceptions or responses to student generated data (as outlined in Table 1).

\section{Student reflections and comments}

Focus group interviews with students occurred during or soon after a specific resource or strategy was introduced by a teacher and used in the classroom. At the end of term there were additional interviews conducted with students immediately following particular lessons. These interviews focused more generally on the students' perceptions of the new practices and strategies.

\section{Reconnaissance, planning and articulating intended action of CPAR}

\section{Reconnaissance}

The project began with an initial meeting between the school leadership team and the researcher, where the notion of 'positivity' had been identified as a key need within the school population. As the discussion progressed it was clear that the staff had felt the impact of systematic emphasis on school achievement and national assessment programs. In their view this had begun to unduly influence their teaching practices to the point of potential disadvantage to quality student learning (an observation noted in 
Hardy’s [2014] statewide study of the impact of the current national assessment agenda in Australia).

The school leadership team shared concerns that were Deweyian $(1897,1916)$ in nature, and inherently critical. The team wanted to ensure that classrooms provided opportunities for the children to develop the personal and psychological resources that would enable them to live productively and positively in the world.

The meetings in the reconnaissance phase opened up an initial communicative space between and amongst the school leadership team. In many ways this phase was an inquiry, an intersubjective dialogic inquiry of the experiences, observations and concerns of the school staff being exchanged and made visible within social space, via a formal institutional setting.

Our aim in the reconnaissance phase was to explore the focus of the felt concern, and to deepen our understanding of it by raising further questions, identifying areas that needed clarification. We worked together to identify existing research that had the potential to bring clarity to these concerns and to inform the development of practices that might address them. The researcher, as critical friend and active member of that communicative space, facilitated these dialogues by asking questions (Why is this a concern? How does this impact on your teaching? Of what relevance is this to the school's aspirations and values?). This also involved the researcher identifying key areas of research that had the potential to offer shape, language and depth, to the practices the teachers might develop as these concerns were addressed in classrooms.

\section{Identifying and unpacking the felt concern}

By the fourth meeting the researcher collaborated with the school's pedagogical coach to synthesise and outline those concerns, mapped against areas of the literature that 
expanded or elaborated them. The two areas of concern emerged: i) the general sense of student disengagement in learning as a personally and culturally valued activity; and ii) the widespread lack of learning-related capabilities amongst students, including limited cognitive, social and psychological strengths.

\section{Countering a sense of disengagement in the potential of learning and school}

Since students were often arriving to class with noticeable levels of anxiety and with an observable lack of focus or preparedness to learn, the first aim was to develop practices that created an explicitly positive and engaging classroom culture. The teachers wanted to develop practices that would foster students’ positive disposition towards learning. This lead to the second, related aim of the project, outlined below.

\section{Building the personal, psychological and social resources that facilitate a positive experience of learning in classrooms}

The teachers had noted, through both anecdotal evidence and school-based assessment processes, that many students did not demonstrate the cognitive, social and psychological strengths that were necessary for positive engagement in learning. Many students gave up and disengaged when they encountered challenging learning tasks. It is possible for personal, psychological and social resources to be effectively taught with appropriate scaffolding, consistency and connectedness to social contexts. The teaching team and researcher found Fredrickson’s (2001) 'broaden and build' theory to be particularly relevant to classroom practice. In this empirical work, Fredrickson found that people responded to challenging circumstances in either one of two ways. The first response entailed a set of limiting, survival-oriented, defensive behaviours that were closely associated with disengagement and primarily negative emotions; the second response entailed a broadening of perspective (looking upwards and outwards towards possibilities, being optimistic) and the intentional building of a repertoire of skills and resources (such as upskilling, seeking help, support and advice 
from others). The second response was shown to entail a range of positive emotions that in turn created a positive and rewarding sense of self-confidence and resiliency.

\section{Articulating intended plans and practices}

The research from the positive youth development field on protective factors, together with the 'broaden and build' theory (Fredrickson 2003, 2001) resonated strongly with the teachers. In their view this research helped to:

a) clarify the felt concern (that students did not appear to have the disposition or resources necessary to engage positively and productively in learning); and

b) offer a research-based heuristic (the kinds of cognitive, psychological and social resources that could be cultivated to facilitate their positive engagement in learning) from which to potentially inform and transform their practice. This clarification helped to shape the first set of action research activities. Together we considered, through cycles of action research, the kinds of practices that could intentionally cultivate students' positive view of themselves as learners, and practices that would deliberately foster the cognitive, social and psychological resources that enabled students to have a positive experience of learning in the classroom.

\section{Cycle 1 An initial cycle of action research}

Three teachers volunteered to work closely with the researcher and the school's pedagogical coach in an action research cycle to further investigate the two areas of concern (outlined above). The teachers were teaching grades 2, $3 \& 4$. Their task was to devise professional development resources and practices that might help teachers to address these concerns. The cycle was facilitated by regular meetings of the action group. This provided a communicative space that facilitated intersubjective dialogue between the life worlds of participants and the system within which they interact (Kemmis et al. 2014). In these meetings the teachers shared their initial ideas 
for incorporating the resources that had been devised and the induction activities for students into their classroom practice for the term. The meetings were carefully facilitated to ensure mutual understandings of each other's views, as well as consideration of the organisational system, and the enactment of the felt concern that shaped each project.

Each teacher also agreed to identify one unit of work they planned to deliver that term, and to meet regularly with the researcher and pedagogical coach to discuss their observations, plans, activities and findings. To provide an evidence base for this cycle, the researcher was invited to conduct close observations of key lessons, collect planning documents and learning resources related to those lessons, talk with students during and after lessons, and debrief with individual teachers before or after the lessons. The action group also took notes of each meeting, reflected on and discussed the experiences of teachers as the weeks unfolded, and shared ideas and resources for supporting a change of practice in the classroom.

One significant outcome of this early work was the development of a poster and 'meme' we entitled PALs (Positive Agile Learners), ${ }^{1}$ that articulated key learning-related behaviours identified in the literature as being correlated with, and characteristic of, people responding positively and productively to life's challenges.

The items on the poster (see Appendix) articulated key learning behaviours to prompt students, or to which teachers could refer students at particularly salient points:

- Performing - paying attention, following directions, working with self control, leading and helping others, staying motivated and completing tasks.

\footnotetext{
1 (C) The acronym PALs (Positive Agile Learning) and its components, materials and illustrations related to Positive Agile Learning are under Creative Commons license O'Brien and Rowlands (2013).
} 
- Innovating - asking questions, finding different ways to do things, brainstorming and creating, overcoming road blocks.

- Taking a risk - having a go, trying something even when you're unsure, experimenting, developing solutions.

- Reflecting - thinking about your own learning, learning from mistakes, looking at the big picture, remembering your 'best self'!

- Overcoming Roadblocks - accepting feedback, being open and flexible, changing tactic and joining in, talking to the teacher.

All teachers in the cycle agreed to use the poster in their classrooms as they continued to teach the identified units of work. The students were introduced to the PALs posters in short introductory sessions, and asked to consider who they were when they were being their 'best self'. The teachers then linked the reminders in the PALs poster to the unit of work, and as the lessons unfolded made use of the poster in various ways.

\section{Enacting \& Observing}

The teachers incorporated PALs into the classroom practices through the delivery of one unit of work (such as a science unit, or a maths unit) selected as a focus for this project. Each of the three teachers thought about how they would engage the students in PALs processes, and shared their ideas with others. Each teacher also devised a set of strategies they would implement for the cycle; these included revising PALs at the beginning of each lesson, or making specific reference to PALs processes during focused learning activities.

Observations of classroom episodes from each teacher were conducted three times over the action research cycle (beginning, middle and end of term). The Year 2 teacher used the PALs poster and processes to support a literacy unit using an activity 
called the 'Hope' book. Classroom observations tracked explicit links to PALs consistently in the teachers' learning-focused and management-focused talk. While there was already a natural alignment between the teacher's talk and the PALs poster, the references to the poster gave the teacher an opportunity to prompt the students, and the students an opportunity to puzzle out for themselves how to respond to particular learning challenges. However, focus group interviews with students indicated that they required some further support to engage each individual in the salient areas of PALs.

The Year 3 teacher used the PALs poster and processes to support a science/maths integrated unit. Over a period of three to four weeks, this teacher devised PALs learning goals where students identified areas that 'got in the way' of their best learning selves (like not knowing their maths facts). Classroom observations showed that consequently, classroom management strategies consistently incorporated the PALs poster as a reference, and as with the first teacher, there was a rise in the use of PALs language (and references to the poster) within pedagogical talk in the classroom. This in turn reflected a transfer of 'responsibility' from the teacher's consistent pedagogical redirections to her use of the PALs poster to engage the students in self-identification of positive/negative learning behaviours.

The Year 4 teacher used the PALs poster and processes to support a maths inquiry unit on chance and data. The students worked in small teams to investigate a problem that required the collection and collation of data, and the development of an action plan based on the data they found. Similarly, the incorporation of the PALs materials were used to reinforce positive engagement in learning throughout the lessons. However, this teacher noted that the PALs materials related to innovating, taking a risk and overcoming roadblocks were particularly powerful in scaffolding her 
students' learning through inquiry. She noted that 'getting them to re-read the PALs and identifying where they were when they were stuck, or if something didn't work out, etcetera, what to do, really helped them to learn about doing inquiry more effectively. And it saved me a lot of talking time!'

As the term drew to a close the group met to share classroom practices and experiences, collate and analyse findings, and consider next steps. Two key outcomes of this cycle were the products developed (PALS posters and the meme for children to engage in) as well as the practices that seemed to have had some value in engaging the children.

In collating our evidence regarding its influence on the students, we considered the notes of fortnightly action group meetings, researcher's detailed field notes and observations, videoed teaching and learning episodes, the teachers' notes and observations, and those of the pedagogical coach (who also observed teaching and learning episodes, sometimes with the researcher and sometimes alone). Table 3 provides a synthesised illustration of the evidence base used analysis of this cycle. It outlines the kinds of extracts and summaries of data collected from teachers, students and from extensive in-class observations that informed our understandings of the 'positive pedagogies' the teachers had devised.

\section{Analysis and Reflection}

The theory of practice architectures shows how pedagogical practices, as both individual experiences and social experiences, come together and evolve in interactive ways, either in sync with each other or out of step to create an experience of learning (Kemmis et al. 2014). Table 2 titled Pedagogies for Positive Learning Identities (after Kemmis et al, 2014) reflects our application of this theory and an analysis of this first cycle, which illustrates the pedagogical practices that the teachers had developed. 
With reference to this table, these entail aspects of the individual sayings (including pedagogical talk that explicitly scaffolded positive thinking and the use of positive language), doings (actions the enables positive engagement and productive directions), and forms of relating (that build positive and productive relationships such as collaborating, sharing or offering assistance). These sayings, doings and relatings were secured through interactionally oriented practices that involved explicit teacher talk and scaffolding (via posters and for teachers in professional learning/communicative spaces). The classroom resources included the PALs poster and resources that rewarded and/or reinforced the modeling of 'positive moments' such as students' engagement in the best self-activity and celebrating goals.

Table 2 Pedagogies for Positive Learning Identities (adapted from Kemmis et al. 2014). 


\begin{tabular}{|c|c|c|c|}
\hline $\begin{array}{l}\text { On the side of } \\
\text { the individual }\end{array}$ & $\begin{array}{l}\text { Practices are interactionally } \\
\text { secured in }\end{array}$ & $\begin{array}{l}\text { Practice architectures } \\
\text { (arrangements and 'set up') } \\
\text { enable and constrain } \\
\text { interaction via }\end{array}$ & $\begin{array}{l}\text { On the side of the } \\
\text { social }\end{array}$ \\
\hline $\begin{array}{l}\text { Sayings and } \\
\text { thinking }\end{array}$ & $\begin{array}{l}\text { 'Thinking positively to learn', } \\
\text { 'using positive language when } \\
\text { learning'. }\end{array}$ & $\begin{array}{l}\text { A classroom that speaks } \\
\text { explicit discourses of } \\
\text { positivity e.g. learning as a } \\
\text { positive, affirming } \\
\text { experience that contributes to } \\
\text { happiness, being my 'best } \\
\text { self'. }\end{array}$ & $\begin{array}{l}\text { Cultural- } \\
\text { discursive } \\
\text { arrangements }\end{array}$ \\
\hline Doings & $\begin{array}{l}\text { 'Acting positively and } \\
\text { productively when learning' } \\
\text { and 'doing learning activities' } \\
\text { to develop a positive sense of } \\
\text { self as a capable learner. }\end{array}$ & $\begin{array}{l}\text { A classroom of possibilities: } \\
\text { learning with purpose and } \\
\text { bringing a positive approach } \\
\text { to each learning situation. }\end{array}$ & $\begin{array}{l}\text { Material- } \\
\text { economic } \\
\text { arrangements }\end{array}$ \\
\hline Relatings & $\begin{array}{l}\text { Relating to other learners in a } \\
\text { 'positive' or 'friendly' way, in } \\
\text { ways that assist others to learn. }\end{array}$ & $\begin{array}{l}\text { Having positive and } \\
\text { productive learning } \\
\text { relationships with yourself } \\
\text { and others. }\end{array}$ & $\begin{array}{l}\text { Social-political } \\
\text { arrangements }\end{array}$ \\
\hline $\begin{array}{l}\text { Learning in a } \\
\text { 'positive' way. }\end{array}$ & & & $\begin{array}{l}\text { Positive ways of } \\
\text { being: cultural, } \\
\text { environment, } \\
\text { economic, social- } \\
\text { political. }\end{array}$ \\
\hline
\end{tabular}

In this way qualities of the students' classroom experiences are enabled and constrained by the practice architectures that hold these arrangements in place (Kemmis, et al, 2014). In this case the teachers in Cycle 1 developed practices to build positive learning resources and identities in the following spaces:

i) the semantic space - creating particular forms of language and meaning that are shared positive dispositions and positive, productive dispositions discursively (including teacher-student, teacher-students, and the studentstudent), using mutual understandings constructed through specific sayings;

ii) the physical space - time - where particular interactions and activities (references to PALs posters, reward cards, etc) are enabled by the shared 
locations, resources and actions (of teacher to student and by, with and for student to student) realised through doings;

iii) the social space - where shared encounters that emphasized the consolidation of positive resources and forms of action were enabled by the teacher and students through particularly enabling ways of related to one another, that result in social relationships that shaped all participants agency and power towards learning positively - through relatings (after Kemmis et al, 2014).

\section{Outcomes}

These classroom practices were easy to incorporate seamlessly into everyday pedagogical practice, and often enhanced scaffolding of learning and even classroom management. All three teachers reported they began to use the PALs posters for lessons or for reasons outside of the initial identified unit. Example practices included:

1. Transitioning to a lesson (from another lesson or after a break from class);

2. Transitioning from one phase of a lesson to another (e.g., from listening to the teacher to working in groups);

3. Redirecting students when they were off-task;

4. Affirming valued behaviour and encouraging other students to do the same;

5. Scaffolding the learning process and effective learning behaviours; and

6. Responding to student queries, questions or quandaries.

In reflection the teachers felt that the PALs could be explicitly taught to students, with younger students needing consistent 'reteaching' or unpacking and modelling with examples. They noted students would initially respond when PALs was explicitly taught, but independent use of the PALS poster or behaviours appeared to be taking longer - requiring reminders and follow ups by teachers. 
The leadership team and researchers met to reflect on the initial research question and to review and analyse the evidence collected and collectively consider the outcomes of this phase and recommendations for moving practices forward. These included the recommendation that PALs could be incorporated into pedagogy. The observations and reflections on activities across the study led to identifying key areas of practice into which PALs could be easily integrated- beginning the day, beginning a lesson, introducing a task (especially a group task), redirecting students who were off-task, and responding to students who did not know what to do next or simply disengaged.

At the end of cycle one the findings were presented to the whole school. A discussion of the felt concern and the extent to which these initial changes in practices attended to these concerns followed. An invitation was extended to any other teachers and school staff interested in participating in future action research cycles aimed to devise and identify practices that promoted positivity for students in the classroom.

Eleven more classroom teachers (across Years Prep to 7) including one LOTE specialist teacher volunteered to join the next cycle of action research, to commence in the new year. They agreed to meet in the action groups regularly, shared their experiences and practices, and undertook individual action research activities designed to identify practices that would promote the positivity of their students in everyday classroom experiences.

\section{Cycle 2 - Planning to incorporate positivity into the classroom}

The second cycle of action research commenced along with a new school year. As with the participants from Cycle 1, the 11 teachers (including the LOTE and HPE teachers) who participated in Cycle 2 agreed to run classes as per usual, each selecting one unit of work as a particular focus for engaging the students in PALs processes 
during the lessons. The researcher and pedagogical coach helped teachers to launch and introduce the PALs poster and process into classrooms in early in the term, and teachers were left to incorporate these ideas into their practice in ways that suited them. The action group (communicative space) continued to meet every fortnight to share experiences, exchange ideas, discuss and analyse practices, and make new plans.

\section{Cycle 2 - Enacting and observing and reflecting}

The teachers reported on their initial attempts to incorporate positivity in the action group meetings. Initially there was uncertainty about how effectively the PALs could be understood by students, particularly in the context of learning a 'new classroom and new teacher'. The pedagogical coach and the researcher observed the flow of three teachers as they implemented PALS into a specific unit of work, and also collected data from (and sought opportunities to observe specific strategies that emerged within) the fortnightly action group meetings.

In those meetings some teachers flourished immediately, some struggled, and others diversified into new practices, including:

- devising PALs goals (one per week that the teacher let students select or gave to students and for which the teacher rewarded them);

- bags of success (similar to the above rewards--bags on wall with goals on front, and teacher used sticky notes onto desk/bags to reinforce); and

- other teachers taking these ideas in combination and devising 'PALs reward cards' (hole-punched cards).

Themes and ideas continued to be explored in meetings. These themes and ideas were collated and prepared for the end of cycle discussion, and included consideration of what works, and what's next? Often the meetings generated further questions about 
positivity, and requests for more research-based information. There was a general sense that as well as the positive agile learning behaviours, more general approaches to identify ways to enable students to change their views of learning and of themselves as learners were needed.

In response, the pedagogical coach or curriculum head would source this information (sometimes independently, and sometimes with the assistance of the researcher). When it was presented in subsequent meetings the discussion often revolved around how these research findings could shape, or be adopted into, pedagogical practices. As an example of this was the notion of changing the way children felt about themselves, which involved the teaching of growth versus fixed mindsets (Dweck 2006). Another area of research that seemed vital to incorporate was social and emotional learning and psychological resources such as hope, efficacy, resilience and optimism (Luthans, Luthans, and Avey 2013). This learning was necessary because it was essential to understand how the teachers and students viewed themselves, to acknowledge that they needed to learn how to stop and think about what (and how) they were thinking and acting, and to have the discipline or capacity to redirect or change tack. This classroom practice came about in two separate incidents.

First, in the Year 3 classroom as the teacher set about working with her students to 'set learning goals', some children became very anxious and stressed, one to the point of inconsolable tears. As the researcher, teacher aide and teacher herself spoke at length to these students, they shared their feelings of anxiety and worry (that they might not be able to achieve their goals) or being overwhelmed (that they were already so far from being a 'good learner' that there was simply too much to focus on). The second incident was in the Year 4 classroom as the teacher struggled with a 
small group of very domineering boys who, while primarily good natured, were also prone to competitiveness and bullying of others.

Over the series of three more meetings we identified and consolidated areas of research that had high application to classrooms and that the teachers wanted to focus on in their practice and/or incorporate within the classroom norms and culture.

\section{Cycle 2 - Analysis and reflection}

In this section we outline key themes that emerged during the analysis and reflection phases of Cycle 2 involving 14 teachers and their students. The practices developed in Cycle 1 were enacted, elaborated and evaluated over the remaining school terms (Terms 2, 3 \& 4) and the participating teachers met fortnightly with the pedagogical coach and/or the researcher to discuss and debrief over experiences, share ideas and strategies, and revise and refine practices. In these meetings, or communicative spaces, the teachers and researchers focused on the review of practices, evidence, and analysis of practices; and took part in explicit reflection, renewed planning. These activities did not unfold as a neat, set of linear steps. Rather it was an iterative and rigorous process of refinement, with practices and resources being shared yet consistently adjusted (as outlined in the earlier descriptions of Cycle 2). The teachers also used this final phase of Cycle 2 to collect and collate their students' perceptions of the practices and resources implemented in their classrooms. The outcomes were overarchingly positive, and are synthesized in Table 3 which captures the classroom practices that were seen as most effective in fostering positive learning dispositions and resources.

Table 3: Classroom practices that facilitate positive pedagogy (data from teachers, students and observations)

\begin{tabular}{llll}
\hline $\begin{array}{l}\text { Classroom } \\
\text { Practice }\end{array}$ & $\begin{array}{l}\text { Data from Teachers } \\
\text { (was similar across } \\
\text { the years) }\end{array}$ & Data from students & $\begin{array}{l}\text { Data from } \\
\text { observations }\end{array}$ \\
\hline $\begin{array}{l}\text { Sayings } \\
\text { and }\end{array}$ & Kids enthusiasm & $\begin{array}{l}\text { Year 1 - I took a risk, I } \\
\text { stayed motivated, I had a }\end{array}$ & $\begin{array}{l}\text { Change in the saying } \\
\text { used (PALs) and the }\end{array}$
\end{tabular}




\begin{tabular}{|c|c|c|c|}
\hline thinking & $\begin{array}{l}\text { Having a positive } \\
\text { language to use with } \\
\text { the children }\end{array}$ & $\begin{array}{l}\text { go, I got past my } \\
\text { roadblocks. }\end{array}$ & $\begin{array}{l}\text { reasons why 'this is } \\
\text { why I teach.' }\end{array}$ \\
\hline & $\begin{array}{l}\text { The language is } \\
\text { powerful- 'how are } \\
\text { you going to } \\
\text { overcome } \\
\text { roadblock?' } \\
\text { A common language } \\
\text { to use when talking } \\
\text { about learning and } \\
\text { how to learn - eg } \\
\text { paying attention, } \\
\text { roadblocks }\end{array}$ & $\begin{array}{l}\text { Year } 4 \text { - I felt encouraged } \\
\text { to learn. I was surprised } \\
\text { because I did better than } \\
\text { my goal so I improved } \\
\text { more. I felt more positive } \\
\text { about learning. } \\
\text { Year } 5 \\
\text { I developed automaticity in } \\
\text { the things I had for goals, } \\
\text { My talking in my head } \\
\text { about learning was more } \\
\text { positive. }\end{array}$ & $\begin{array}{l}\text { Changes in sayings } \\
\text { and thinking then } \\
\text { affected the activities } \\
\text { and actions in the } \\
\text { classroom and the } \\
\text { ways of relating with } \\
\text { one and other. }\end{array}$ \\
\hline Doings & $\begin{array}{l}\text { Having the PAL } \\
\text { awards and postcards } \\
\text { to reinforce positive } \\
\text { behaviour. } \\
\text { Goals gives the } \\
\text { teacher and the } \\
\text { students particular } \\
\text { areas to focus on. } \\
\text { Children more } \\
\text { prepared to 'have-a- } \\
\text { go' with learning } \\
\text { activities. } \\
\text { Children accepting } \\
\text { mistakes as learning } \\
\text { opportunities. }\end{array}$ & $\begin{array}{l}\text { Year } 1 \text { - I figured out how } \\
\text { to read more tricky books, I } \\
\text { could look at my goal to } \\
\text { remember what I have to } \\
\text { learn } \\
\text { Year } 3 \text { - Bags of Success } \\
\text { were great; I could see that } \\
\text { I achieved something; I } \\
\text { reached a new level of } \\
\text { learning } \\
\text { Year } 4 \text { - Before I didn't } \\
\text { learn much because I was } \\
\text { always naughty but having } \\
\text { PALs helped me to } \\
\text { overcome roadblocks and } \\
\text { not get angry, so I did lots } \\
\text { more learning and I didn't } \\
\text { get into trouble nearly as } \\
\text { much. } \\
\text { Year } 5 \text { Setting goals that } \\
\text { were achievable instead of } \\
\text { ”I need to improve my } \\
\text { maths, which is just too } \\
\text { big.” Being able to 'see' } \\
\text { my goal and then 'see' that } \\
\text { I achieved them. }\end{array}$ & $\begin{array}{l}\text { Developing goal } \\
\text { setting in learning } \\
\text { activities that were } \\
\text { held together by the } \\
\text { norms of PALs. }\end{array}$ \\
\hline Relatings & $\begin{array}{l}\text { Their attitude } \\
\text { towards their } \\
\text { learning has changed. } \\
\text { Student becoming } \\
\text { more independent to } \\
\text { problem solve } \\
\text { instead of asking me }\end{array}$ & $\begin{array}{l}\text { Year } 1 \text { - I got past my } \\
\text { roadblock in writing, I } \\
\text { helped others with their } \\
\text { learning } \\
\text { Year } 3 \text { - it gave me words } \\
\text { to talk to my teacher about } \\
\text { learning }\end{array}$ & $\begin{array}{l}\text { Deep emotional } \\
\text { engagement in their } \\
\text { practice, resonating } \\
\text { with their personal } \\
\text { choices/values based } \\
\text { 'reasons for } \\
\text { teaching' that } \\
\text { provided a sense of } \\
\text { satisfaction and } \\
\text { professional } \\
\text { pleasure. }\end{array}$ \\
\hline
\end{tabular}


Using Kemmis et al’s (2014) practice architectures, Table 3 outlines the sayings, doings and relatings that were considered most effective by teachers and students, which are presented in alignment with the observations undertaken over cycles 1 and 2. Teachers found the use of language to scaffold and positively boost their students' general disposition as well as the use of specific strategies to improve learning to be highly effective; the development of physical resources (such as posters and reward cards) provided valuable support; and affirmed the use of specific social practices that consolidated and made positivity part of learning to be important. Students responded explicitly to the use of key words and phrases (such as 'taking a risk' and talking about 'road blocks'), and found the use of specific learning goals that targeted both academic achievement as well as personal growth to be encouraging.

\section{Concluding comment}

The purpose of CPAR is to work with others to make a shared social practice more coherent, just, rational, informed, satisfying and sustainable (Kemmis et al. 2014). The work undertaken by the teachers in this school over six school terms (an 18month period) entailed a sustained focus on, and development of, practices to address an important felt concern: of caring about the positive development of their students' cognitive, social and psychological needs in the 'era of accountability' that emphasises assessment and standardised testing (Comber and Nixon 2001; Hardy 2014). As these teachers expressed and then researched their concern, they were able to identify and make use of pedagogical practices that effectively scaffolded the development of students’ positive cognitive, social and psychological resources within the day-to-day sayings, doings and relatings of classroom practice.

These pedagogical practices have been summarised and presented positive pedagogies (to reflect the focus on building positive and enabling cognitive, social 
and psychological resources for learning). The data generated over two action research cycles, allowed us to identify pedagogical practices that enabled the development of these resources and dispositions for students in the classroom. These practices include teacher talk that incorporates the scaffolding of positive cognitive, social and emotional resources for students along with instruction, the supplementation of lessons with resource building materials, and the development of individualised learning goals that target the development of positive cognitions, emotions and experiences. We also provided a detailed commentary of the action research cycles (and related professional learning) that classroom teachers undertook in the process of investigating, developing and refining the 'positive pedagogies' presented here. 


\section{References}

Australian Education Union. 2009. New Educators Survey 2008: Results and Report. http://www.aeufederal.org.au/Publications/2009/Nesurvey08res.pdf

Benson, P.L. 2007. "Developmental Assets: An Overview of Theory, Research and Practice." In Approaches to positive youth development, edited by R. K. Silbereisen and R.M. Learner, 33-58. Thousand Oaks, CA: Sage Publications.

Carr, W. 2007. "Educational Research as a Practical Science.” InternationalJjournal of Research \& Method in Education 30 (3): 271-286.

Comber, B., and P. Thomson. 2001, June. "Just New Learning Environments: New Metaphors and Practices for Learners and Teachers in Disadvantaged Schools." In Keynote paper presented at the Department for Education and Skills, Experiencing Change, Exchanging Experience Virtual Conference, June (Vol. 25).

Dewey, J. 1897. The Significance of the Problem of Knowledge. University of Chicago Press.

Dewey, J. 1916. Democracy and Education: An Introduction to Philosophy of Education. New York, NY:Macmillan.

Dweck, C. 2006. Mindset: The New Psychology of Success. New York:Random House.

Fredrickson, B. L. 2001. "The Role of Positive Emotions in Positive Psychology: The Broaden-and-build Theory of Positive Emotions.” American Psychologist 56 (3): 218-266.

Fredrickson, B. L. 2003. “The Value of Positive Emotions.” American Scientist 91 (4): 330-335.

Fredrickson, B. 2006. "Unpacking Positive Emotions: Investigating the Seeds of Human Flourishing.” The Journal of Positive Psychology 1 (2): 57-59.

Fredrickson, B. 2009. Positivity. New York, NY: Crown Publishers.

Furlong, M. J., R. Gilman, and E.S. Huebner. 2014. Handbook of Positive Psychology in Schools. $2^{\text {nd }}$ ed. New York, NY: Routledge.

Gilman, R., E. S. Huebner, and M.J. Furlong. 2014. "Toward a Science and Practice of Positive Psychology in Schools: A Conceptual Framework.” In Handbook of Positive Psychology in Schools $2^{\text {nd }}$ ed, edited by M. J. Furlong, R. Gilman, and E.

S. Huebner, 3-11. New York, NY: Routledge.

Grootenboer, P. 2013. "Praxis and Mathematics Education.” Pedagogy, Culture and Society 21 (2): 321-342. 
Hardy, I. 2014. "A Logic of Appropriation: Enacting National Testing (NAPLAN) in Australia.” Journal of Education Policy 29 (1): 1-18.

Huebner, E. S. and K.J. Hills. 2011. "Does the Positive Psychology Movement have Legs for Children in Schools?” The Journal of Positive Psychology: Dedicated to Furthering Research and Promoting Good Practice 6 (1): 88-94.

Hughes, K., A. Bullock, and R.J. Coplan. 2014. "A Person-centred Analysis of Teacher-child Relationships in Early Childhood." British Journal of Educational Psychology 84: 253-267.

Kemmis, S. 2009. “Action Research: A Practice-Based Practice.” Educational Action Research Journal 17 (3): 463-474. doi: 10.1080/09650790903093284

Kemmis, S. 2010. "Research for Praxis: Knowing Doing." Pedagogy, Culture \& Society, 18 (1): 9-27. doi: 10.1080/14681360903556756

Kemmis, S. 2012. "Researching Educational Praxis: Spectator and Participant Perspectives.” British Educational Research Journal, 38 (6): 885-905.

Kemmis, S., R. McTaggart, and R. Nixon. 2014. "The Action Research Planner: Doing critical participatory action research.” Singapore: Springer.

Kemmis, S., J. Wilkinson, C. Edwards-Groves, I. Hardy, P. Grootenboer, and L. Bristol. 2014. Changing Education, Changing Practices. Singapore: Springer.

Luthans, B. C., K. W. Luthans, and J.B. Avey. 2013. "Building the Leaders of Tomorrow: The Development of Academic Psychological Capital.” Journal of Leadership \& Organizational Studies, 21(2), 191-199.

Luttenberg, J., Meijer, P., and H. Oolbekkink-Marchand. 2017. "Understanding the complexity of teacher reflection in action research.” Educational Action Research, 25:1, 88-102, DOI: 10.1080/09650792.2015.1136230.

Lyubomirsky, S., D. Schkade, and K.M. Sheldon. 2005. "Pursuing Happiness: The Architecture of Sustainable Change.” Review of General Psychology, 9 (2): 111131.

Makar, K., \& O’Brien, M. (2013). Blurring the boundaries: The transformative nature of research participation. In M. Baguley, G. Curro, P. A. Danaher \& W. Midgley (Eds.)The role of participants in education research: Epistemologies, ethics, and methods (pp. 110-125). New York: Routledge.

Mertens, D. M. 2014. Research and Evaluation in Education and Psychology: Integrating Diversity with Quantitative, Qualitative and Mixed Methods. Thousand Oaks, CA: Sage Publications. 
O’Brien, M. 2017. "Positive Behaviour Management: Building Positive Learning Identities and Engagement in Learning." In Teaching Middle Years: Rethinking Curriculum, Pedagogy and Assessment, edited by D. Pendergast, N. Bahr, and K. Main, 243-264. Sydney, NSW:Allen and Unwin.

Park, N., and C. Peterson. 2006. "Character Strengths and Happiness among Young Children: Content Analysis of Parental Descriptions.” Journal of Happiness Studies, 7: 323-341.

Peterson, C., and M.E.P. Seligman. 2004. Character Strengths and Virtues: A Handbook and Classification. Washington DC: American Psychological Association.

Pianta, R. C. and M.W. Stuhlman. 2004. "Teacher-child Relationships and Children’s Success in the First Years of School.” School Psychology Review, 33 (3): 444458.

Pietarinen, J., T. Soini, and K. Pyhältö. 2014. "Students’ Emotional and Cognitive Engagement as the Determinants of Well-being and Achievement in School." International Journal of Educational Research, 67: 40-51.

Ponte, P. 2006. Quality of action research: “'What is it', 'What is it for' and 'What next'?”. Educational Action Research, 14(4): 451-57.

Ponte, P. and K. Rönnerman. 2009. Pedagogy as human science, bildung and action research: Swedish and Dutch reflections. Educational Action Research 17 (1): 155-167. DOI: 10.1080/09650790802667550.

Shernoff, D. J. 2013. Optimal Learning Environments to Promote Student Engagement. New York, NY: Springer.

Silver, R. B., J. R. Measelle, , J. M. Armstrong, and M.J. Essex. 2005. “Trajectories of Classroom Externalizing Behaviour: Contributions of Child Characteristics, Family Characteristics, and the Teacher-child Relationship during the School Transition.” Journal of School Psychology, 43: 39-60.

Skinner, E. A., T. A. Kindermann, and C. Furrer. 2009. “A Motivational Perspective on Engagement and Disaffection: Conceptualization and Assessment of Children's Behavioural and Emotional Participation in Academic Activities in the Classroom.” Educational and Psychological Measurement, 69: 493-524.

Wang, M. and R. Holcombe. 2010. "Adolescents' Perceptions of School Environment, Engagement and Academic Achievement in Middle School." American Educational Research Journal, 47: 633-662.

Wilkinson, J. and S. Kemmis, S. 2014. "Practice Theory: Viewing Leadership as Leading." Educational Philosophy \& Theory: Incorporating ACCESS. doi: http://dx.doi.org/10.1080/00131857.2014.976928 
Willms, J. D. 2003. Student Engagement at School: A Sense of Belonging and Participation. OECD Publishing, .http://www.oecd.org/education/school/programmeforinternationalstudentassessm entpisa/33689437.pdf

Wu, J., J.N. Hughes, and O. Kwok. 2010. "Teacher-student Relationship Quality Type in Elementary Grades: Effects on Trajectories for Achievement and Engagement.” Journal of School Psychology, 48: 337-355. 
Appendix A: Positive Agile Learners (O’Brien \& Rowlands, 2013).

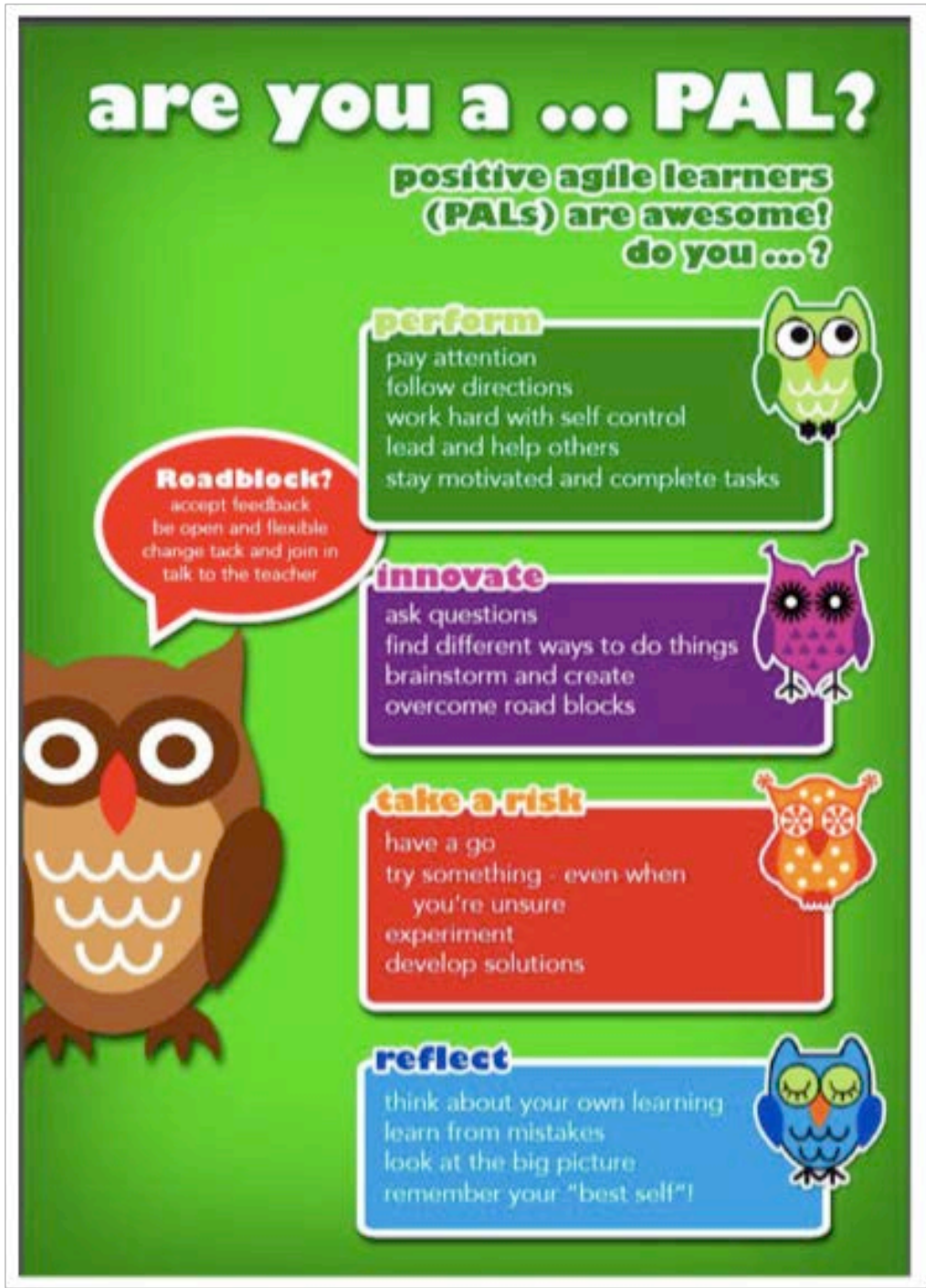

